\title{
Studies on Change in Physico-Chemical Parameters of Pineapple Fruits of Cultivars Kew and MD-2 during Storage at Ambient Temperature
}

\author{
Md. Manzar Hossain*, Tokivi Zhimomi, P.S. Nupani and A.K. Singh
}

Central Institute of Horticulture, Department of Agriculture, Co-operation and Farmer Welfare, Ministry of Agriculture and Farmer Welfare, Government of India, Medziphema, Nagaland-797106, India

*Corresponding author

\section{A B S T R A C T}

\begin{tabular}{|l|}
\hline Ke y w o r d s \\
Pineapple, Storage, \\
Kew, MD-2, TSS \\
\hline Article Info \\
\hline $\begin{array}{l}\text { Accepted: } \\
\text { 06 May } 2018 \\
\text { Available Online: } \\
\text { 10 June } 2018\end{array}$ \\
\hline
\end{tabular}

\section{Introduction}

Pineapple (Ananas comosus L.) is a tropical plant of family Bromeliaceae and it is widely cultivated in India. The major growing states are west Bengal, Assam, Kerala, Karnataka, Tripura, Meghalaya and Nagaland. The area under pineapple cultivation in India is about 121.09 thousand ha and it produces around 2038.44 thousand MT pineapple in the year 2016-17 (Horticultural statistics at a glance 2017). The post-harvest loss of fruits varies from farmer field to consumer level is nearly $21 \%$ and sometimes it goes upto $40-50 \%$ (Kabir et al., 2010). Fresh pineapple fruit is consumed as desserts and salad. It can be processed into juice, canned flesh, fruit

\begin{abstract}
Storage studies of matured green pineapple fruits of cultivar Kew and MD-2 were carried out at ambient condition. The physiological weight loss (PLW) was highest $(9.62 \pm 0.65 \%)$ in MD-2 cultivar whereas the PLW was lowest $(9.16 \pm 0.31 \%)$ in Kew cultivar on $9^{\text {th }}$ day after storage (DAS). The firmness of fruit was highest $\left(2.86 \pm 0.56 \mathrm{kgcm}^{-2}\right)$ in MD-2 and during storage. Titrable acidity was low $9^{\circ}$ DAS and there was significant difference lowest $(8.66 \pm 0.66 \%)$ in Kew on $9^{\text {th }}$ DAS. The reducing $(6.60 \pm 0.82 \%)$ was highest whereas the non-reducing $(1.58 \pm 0.58)$ was lowest in Kew on $9^{\text {th }}$ DAS. The overall acceptability (OAA) score was highest $(8.03 \pm 0.11)$ in MD-2 on $6^{\text {th }}$ DAS.
\end{abstract}

cocktail, crushed pineapple, fruit punch, frozen pineapple, yoghurt, pineapple powder, freeze-dried pineapple, wines, sauces, jams, marmalades and confectionery product. Pineapple fruits are considered as good source of carbohydrates, dietary fiber and minerals such as calcium, iron, phosphorus, sodium and potassium (Hossain and Bepary, 2015). Pineapple fruit also contains some vitamins including $\mathrm{A}$, thiamine, riboflavin, niacin, pantothenic acid, pyridoxine, folate and ascorbic acid (Ancos et al., 2017). The fruit is also rich in bromelin and it has pharmacological as well as meat tenderizing properties (Lobo and Siddiq, 2017; Rekha et al., 2013). The important cultivar grown in India is Cayenne, Mauritius, Vazhakulam 
pineapple, Amritha, Kew, Giant Kew Queen and MD-2 (http://prsvkm.kau.in/book/variety). The quality of pineapple fruit changes rapidly during storage and hence it influences the acceptability of the consumer (Shamsudin et al., 2007; Jha et al., 2012). Pineapple is a non- climacteric fruit (Ding and Syazwani, 2016) and fruit does not continue to ripen or sweeten significantly after harvest. Therefore, fruit must be harvested until it reaches to the matured green stage. Pineapple fruit is perishable in nature and postharvest loss of the fruit varies from 5 to $20 \%$ (http://www.nistads.res.in/indiasnt2008/t6rural /t6rur14.htm). Postharvest loss is depend on the fruit production area, mode of transportation, road condition and market distance. The variation in postharvest storage life and quality of pineapple fruit during storage in the different cultivar have been reported by Ali et al., (2015a). Therefore, the study was carried out to access the change in physico-chemical attributes and quality parameters during storage at ambient temperature in the ambient condition.

\section{Materials and Methods}

Pineapple fruit were harvested from the farm of Central institute of Horticulture, Medziphema and brought to the Laboratory for physico-chemical and organoleptic studies during storage at ambient temperature $(33 \pm 5$ $\left.{ }^{\circ} \mathrm{C}\right)$ and R.H ( $\left.85 \pm 6 \%\right)$. A total 12 number of mature green pineapple fruits of each variety were used in the experiments. The experiments were performed in a completely randomized design with 3 replication and physico-chemical properties were analyzed at 3 days interval during storage.

\section{Physiological weight loss percentage (PLW)}

Physiological weight losses were determined as described by Dhar et al., 2008, using the following formula;
$\operatorname{PLW}(\%)=\frac{\text { Initial fruit weight }(\mathrm{g})-\text { Final fruit weight }(\mathrm{g})}{\text { Initial fruit weight }(\mathrm{g})} \times 100$

\section{Fruit Firmness $\left(\mathrm{kgcm}^{-2}\right)$}

Fruits firmness of peeled tissue was measured with penetrometer (FT 327, Made in Italy) fitted with a probe of $15 \mathrm{~mm}$ diameter.

\section{Chemical analysis}

The total soluble solids were measured with the help of Digital refractometer (ATAGO PAL-3, Made in Japan).

Total titrable acidity was determined by titrating a known weight of juice with $0.1 \mathrm{~N}$ $\mathrm{NaOH}$ solution using phenolphthalein as an indicator.

The results were expressed as percent anhydrous citric acid (w/w) (Ranganna, 1994).

Vitamin $\mathrm{C}$ was analyzed as described by AOAC method. Reducing and non-reducing sugars are measured by using Lane and Eynon Method (Ranganna, 1994).

\section{Sensory analysis}

Sensory evaluation was done based on 9-point hedonic scale and score were recorded based on these parameters (Liked extremely $=9$, Liked very much $=8$, Liked moderately $=7$, Liked slightly $=6$, neither liked nor disliked $=5$, Disliked slightly $=4$, Disliked moderately $=3$, Disliked very much $=2$, Disliked extremely $=1$ ). A piece of peeled and cored pineapple fruits was subjected to sensory evaluation by 10 semi-trained panelists from the institute.

\section{Statistical analysis}

The collected data from the experiment were statistically analyzed as one way ANOVA by using Graph pad Prism 7.0 trial version. 


\section{Results and Discussion}

\section{PLW Percentage}

The physiological weight loss (PLW) plays major role to determine the post-harvest life and quality of the pineapple fruit. PLW was studies in the two cultivar of pineapple viz., kew and MD-2 and results were expressed in the Figure 1.

From Figure, it indicates that PLW was high in case of MD-2 cultivar whereas in Kew cultivar the PLW was low. The PLW percentage varies from 0 to $9.16 \pm 0.31 \%$ in Kew variety and in the MD-2, it varies from 0 to $09.62 \pm 0.65 \%$ during storage period from 0 to 9 days and there were significant difference $(p \leq 0.05)$ in the PLW in both the variety. From the graph of Figure 1 shows that PLW varies with storage time and it increases with increase in number of storage day and it is also reported by Al- Obeed and Harhash (2006).

The loss in moisture and subsequent reduction PLW depends on the water content present in the fruit. Hence, the PLW is more in MD-2 cultivar than Kew may be due to presence of higher amount of water content than Kew cultivar.

\section{Fruit firmness}

Fruit firmness is important parameter which helps to determine the shelf life and quality of the fruit. The firmness of pineapple fruit was highest (in Kew, $5.8 \pm 0.23 \mathrm{~kg} \mathrm{~cm}^{-2}$; in MD-2, $5.8 \pm 0.75 \mathrm{kgcm}^{-2}$ ) when harvested at mature green stage where as the firmness was found to be lowest on the $9^{\text {th }}$ days after harvest and it was $2.36 \pm 0.20 \mathrm{kgcm}^{-2}$ in Kew and $2.86 \pm 0.56$ $\mathrm{kgcm}^{-2}$ in MD-2 cultivar and there was significant difference $(p \leq 0.05)$ in the firmness fruit during storage. From the experiment, it was observed that in both the varieties of pineapple the firmness decreases with increase in the storage period and it is given in Figure 2. It was also observed that the firmness of pineapple fruit of MD-2 variety was better than Kew during storage. As firmness of the fruit decreases the post-harvest storage life of pineapple fruit also decreases and it may be due to deteriorative changes associated with the senescence (Cordenunsi et al., 2003). The decomposition of cell wall structure such primary cell wall and middle lamella causes the reduction in mechanical strength as result the firmness of the fruit decreases.

\section{Total soluble solids}

Total soluble solids (TSS) indicate the maturity stage and quality of the fruit. The TSS of pineapple in cultivar Kew was $14.36 \pm 1.18{ }^{\circ} \mathrm{B}$ and in MD-2 was $12.30 \pm 0.29$ ${ }^{\circ} \mathrm{B}$, when harvested at matured green stage. In case of Kew variety the TSS changes from $14.36 \pm 1.18{ }^{\circ} \mathrm{B}$ to $18.18 \pm 0.32{ }^{\circ} \mathrm{B}$, whereas in case of MD-2 variety the TSS changes from $12.30 \pm 0.29{ }^{\circ} \mathrm{B}$ to $15.60 \pm 0.31{ }^{\circ} \mathrm{B}$ during storage.

From the observation it was found that in both the cases there was significant difference $(\mathrm{p} \leq 0.05)$ in the TSS during storage of fruits. Figure 3 shows the variation in TSS during storage of pineapple fruits and it also indicates that TSS is increases with increase in the storage time and similar results were also reported by Kamol et al., (2014) and Ali et al., (2015a). The increase in TSS may be due to conversion of starch into the sugar. Soluble solid percentage is a function of dissolved solid and water content present in the fruit (Farooq et al., 2012).

Thus, increase in TSS might also be due to presence of low moisture content in the fruit or concentration of dissolved solid due to loss of moisture content during storage. 
Fig.1 Change in PLW (\%) during storage of pineapple cultivar Kew and MD-2

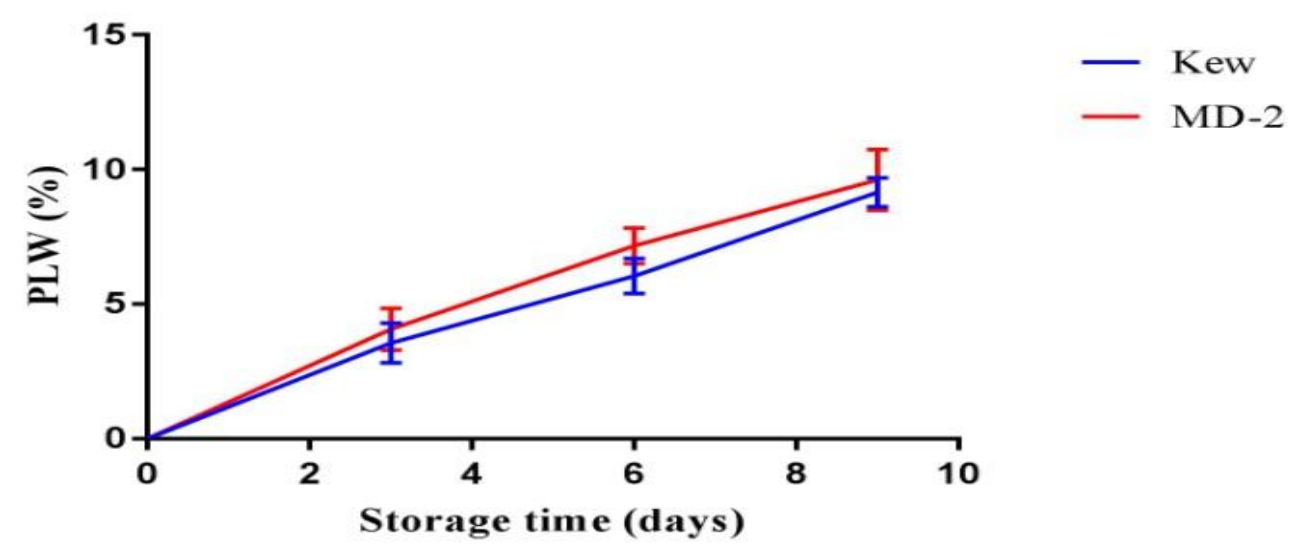

Fig.2 Change in texture $\left(\mathrm{kgcm}^{-2}\right)$ during storage of pineapple cultivar Kew and MD-2

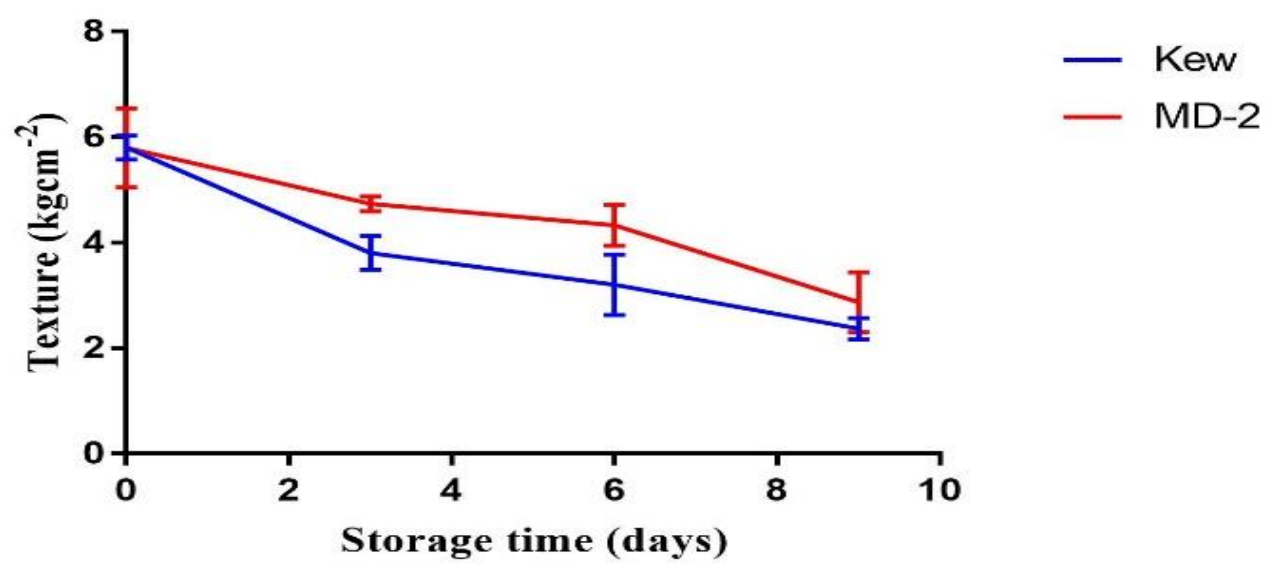

Fig.3 Change in TSS ${ }^{\circ} \mathrm{B}$ during storage of pineapple cultivar Kew and MD-2

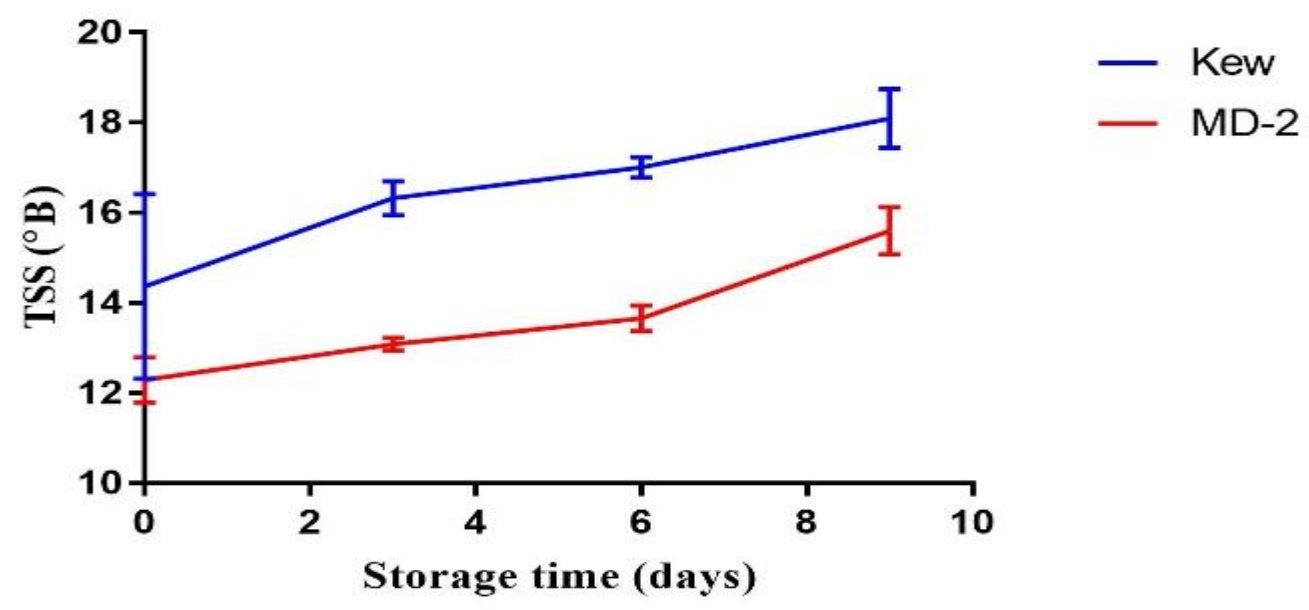


Fig.4 Change in acidity (\%) during storage of pineapple cultivar Kew and MD-2

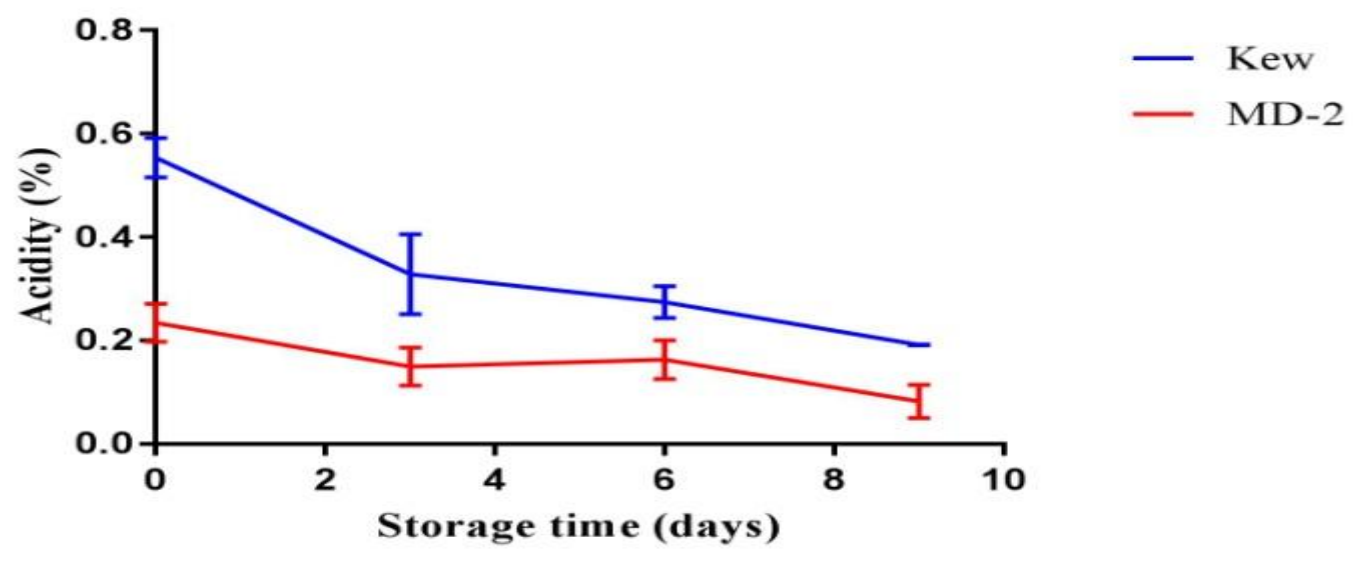

Fig.5 Change in Vitamin C during storage of pineapple cultivar Kew and MD-2

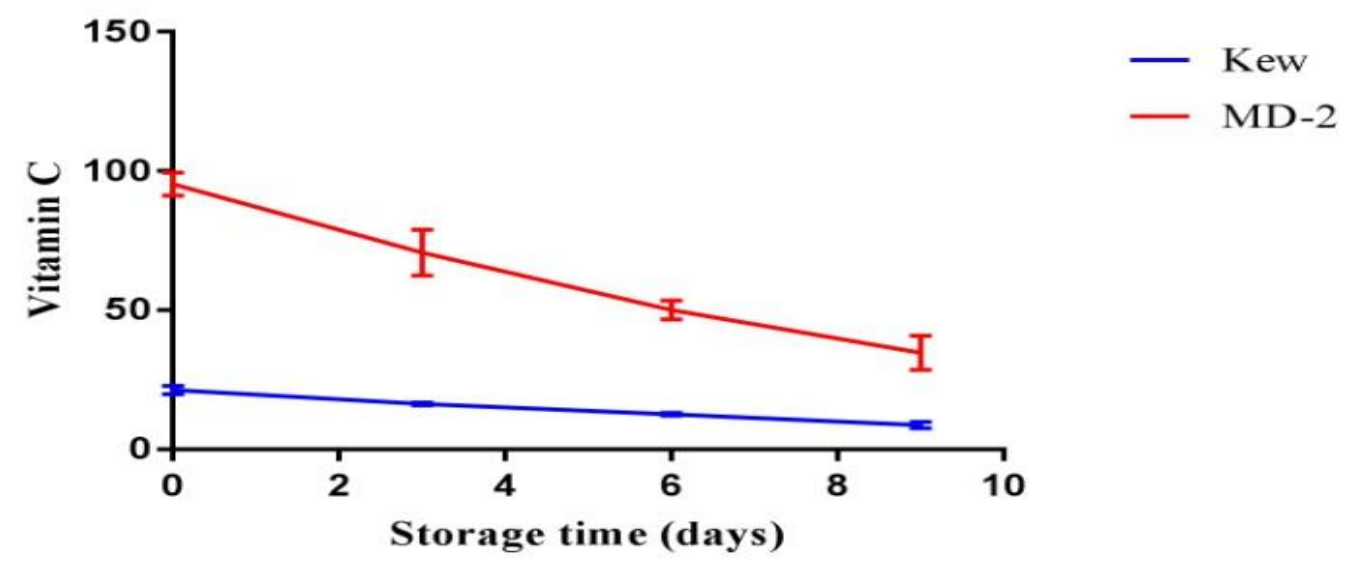

Fig.6 Change in reducing sugar during storage of pineapple cultivar Kew and MD-2

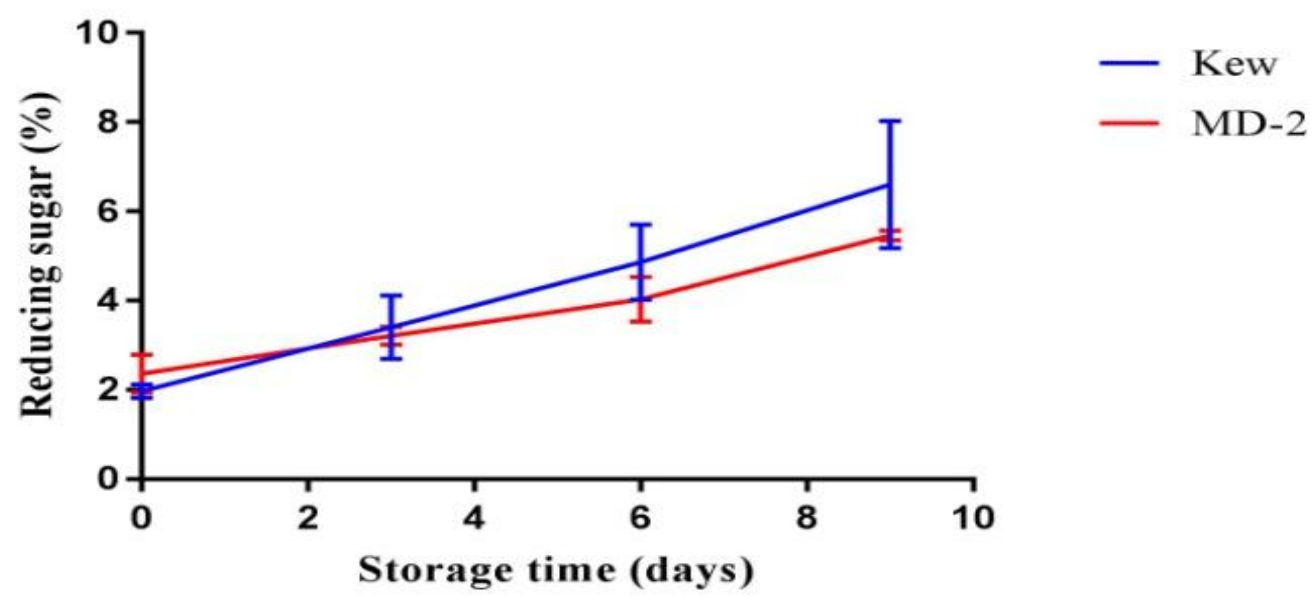


Fig.7 Change in non-reducing sugar during storage of pineapple cultivar Kew and MD-2

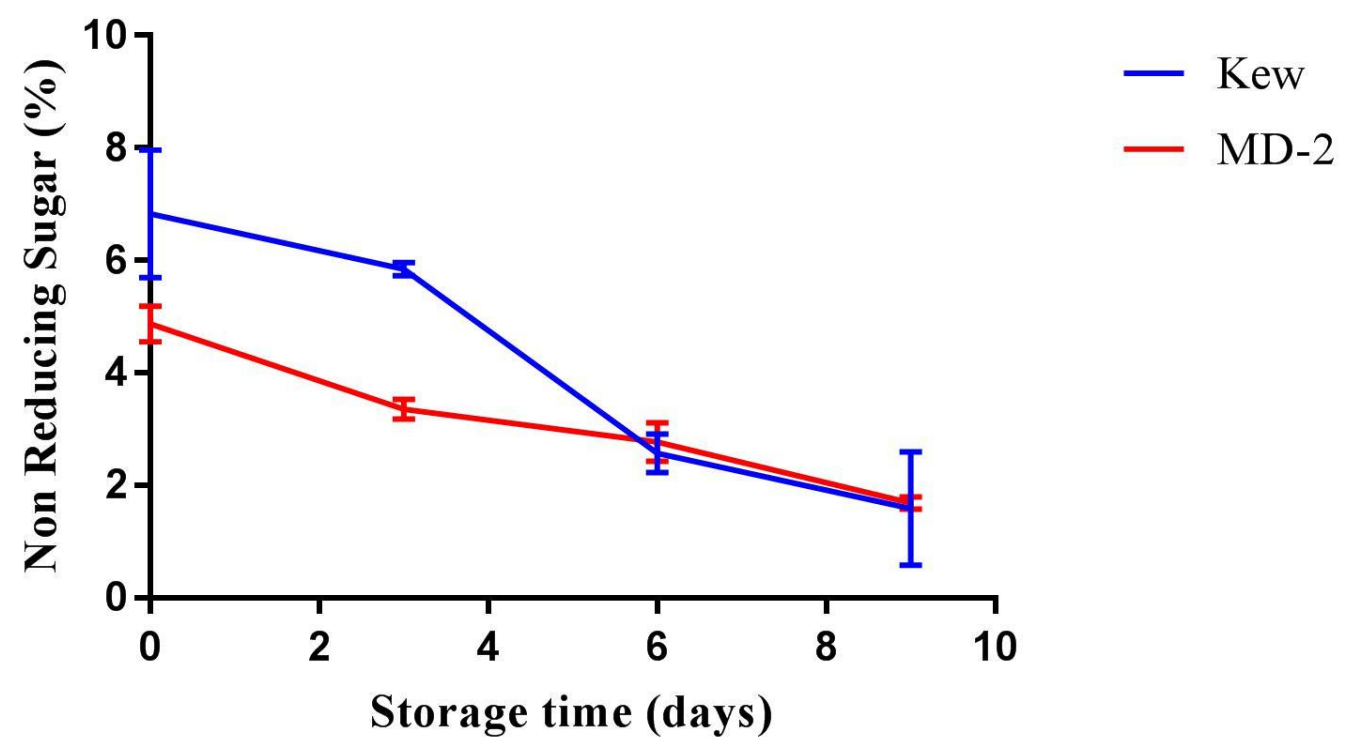

Fig.8 Change in overall acceptability (OAA) score during storage of pineapple cultivar Kew and MD-2

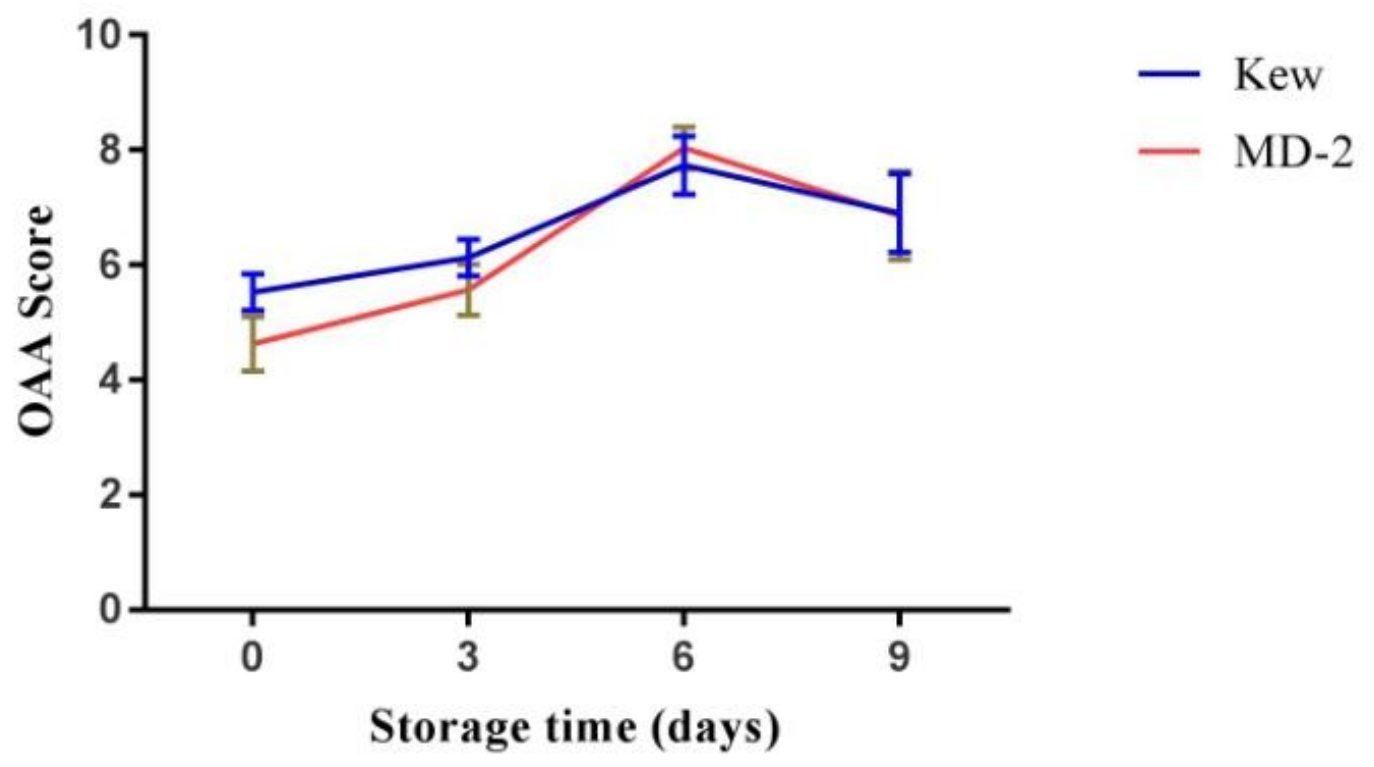

\section{Titrable acidity}

From the experiment it was found that the acidity percentage in Kew variety was $0.55 \pm 0.02,0.32 \pm 0.04,0.27 \pm 0.18$ and 0.19 ; whereas in MD-2 variety was $0.23 \pm 0.02$, $0.15 \pm 0.02,0.16 \pm 0.02$ and $0.08 \pm 0.01$ during storage on 0 day, $3^{\text {rd }}$ days, $6^{\text {th }}$ days and $9^{\text {th }}$ days respectively. The Figure 4 shows that acidity percentage decreases with increase in 
the storage time and similar finding was reported by Ali et al., (2015b), during storage of pineapple fruit.

\section{Vitamin C}

Vitamin $\mathrm{C}$ is act as an antioxidant and may play the important role to improve the storage life of fruits. The vitamin $\mathrm{C}$ content were $21.33 \pm 0.88, \quad 16.33 \pm 0.33, \quad 12.50 \pm 0.28$ and $8.66 \pm 0.66$ present in Kew and $95.33 \pm 2.40$, $70.66 \pm 4.80,50.00 \pm 2.00$ and $34.66 \pm 3.53$ in MD-2 variety during storage on 0 day, $3^{\text {rd }}$ days, $6^{\text {th }}$ days and $9^{\text {th }}$ days respectively. From the Figure 5 it is observed that the vitamin $\mathrm{C}$ content in both the cultivar of pineapple fruit is decreases with increase in the storage time and similar finding was also reported by Kabir et al., (2010), Hong et al., (2013) and Ali et al., (2015b).

In case of MD-2 variety it is observed that vitamin $\mathrm{C}$ decreases sharply with the increase in the storage period whereas in case of Kew variety the Vitamin $\mathrm{C}$ decreases gradually with storage time.

\section{Reducing sugar}

In Kew variety reducing sugar percentage changes from $1.96 \pm 0.08$ to $6.60 \pm 0.82$ and in MD-2 variety it changes from $2.36 \pm 0.24$ to $5.46 \pm 0.06$ during storage period and in both the cultivar, reducing sugar changes significantly $(p \leq 0.05)$. Figure 6 shows that reducing sugar of the fruit increases with increase in the storage period in both the cultivar and similar finding was reported by Farooq et al., (2012).

It has been also observed that in Kew there was slightly more increase in the reducing sugar than MD-2. During storage of pineapple fruit the conversion of starch into sugar was continued as result, there was increase in the reducing sugar.

\section{Non-reducing sugar}

Figure 7 shows that non-reducing sugar significantly differ at $(\mathrm{p} \leq 0.05)$ during storage in both the cultivar. The non-reducing sugar percentage were $6.83 \pm 0.65,5.84 \pm 0.06$, $2.57 \pm 0.19$ and $1.58 \pm 0.58$ recorded in Kew variety whereas in MD-2 the reducing sugar were $4.87 \pm 0.18,3.35 \pm 0.10,2.76 \pm 0.20$ and $1.68 \pm 0.06$ recorded during storage on 0 day, $3^{\text {rd }}$ days, $6^{\text {th }}$ days and $9^{\text {th }}$ days respectively. Non-reducing sugar decreases with increase in the storage duration as given in Figure 7 and it is supported by the finding of Dhar et al., (2008).

\section{Overall acceptability}

The statistical analysis for overall acceptability showed that there is significance difference at $(\mathrm{p} \leq 0.05)$. The highest score was observed in MD-2 (8.033 \pm 0.11$)$ and in Kew $(7.73 \pm 0.16)$ on $6^{\text {th }}$ days after storage. Over all acceptability of pineapple fruit harvested at mature green stage are increases with increase in the storage time at a certain period and again it decreases as storage time prolonged. The pineapple stored at ambient temperature continued to respire and hence it reduced the quality of fruit (Fig. 8).

Loss in moisture content, firmness and biochemical changes affects the texture, flavor and visual quality of fruit as the storage period increases.

Post-harvest weight loss of pineapple fruits increases with increase in the storage period. Firmness of fruit, Titrable acidity and vitamin $\mathrm{C}$ were decreases with increase in storage period. Total soluble solid, reducing, nonreducing sugar of the fruit increases with increase in the storage duration. Highest overall acceptability (OAA) score of pineapple fruit was recorded on $6^{\text {th }}$ day after storage. 


\section{Acknowledgement}

Authors thanks to Dr. Lallan Ram, Director, Central Institute of Horticulture, Medziphema for allowing the research studies in the institute.

\section{References}

Al- Obeed, R.S. and Harhash, M.M., 2006. Impact of postharvest treatments on storage life and quality of "Mixican" Lime. J. Adv. Agric. Res. 11(3): 533549.

Ali, S.M.Y., Ahiduzzaman, M., Akhter, S., Biswas, M. A. M., Iqbal, N., Onik, J.C., and Rahman, M. H., 2015 . Comparative effects on storage period of varieties Pineapple fruits. Res. Agric. Livest. Fish. 2 (3): 395-410.

Ali, S.M.Y., Ahiduzzaman, M., Hossain, M. M., Ali, M. A., Biswas, M. A. M., Rahman, M. H., and Onik, J.C., 2015a. Physical and Chemical Characteristics of Pineapples Grown in Bangladesh. Int. J. Bus. Soc. Sci. Res. 3(4): 234-246.

Ancos, B., Moreno, C. S., and Adolfo, G.A.G., 2017. Pineapple composition and nutrition. Handbook of Pineapple Technology Production, Postharvest Science, Processing and Nutrition, Edited by María Gloria Lobo and Robert E. Paull. Published by John Wiley \& Sons, Ltd. U.K.

Cordenunsi, B.R., Nascimento, J.R.O., Lajolo, F.M., 2003. Physico-chemical changes related to quality of five strawberry fruit cultivars during coolstorage. Food Chemistry 83, 167-173.

Dhar, M., Rahman, S.M., and Sayem, S.M., 2008. Maturity and Post-Harvest Study of Pineapple with Quality and Shelf Life under Red Soil. Int. J. Sustain. Crop Prod. 3(2): 69-75.

Ding, P. and Syazwani, S., 2016. Physicochemical quality, antioxidant compounds and activity of MD-2 pineapple fruit at five ripening stages. International Food Research Journal 23(2): 549-555.

Farooq, Rab, A., Khan, N., and Iqbal, I., 2012. Physico-chemical quality of apple cv. Gala must fruit stored at low temperature. FUUAST J. BIOL., 2(1): 103-107.

Hong, K., Xu, H., Wang, J., Zhang, L., Hu, H., Jia, Z., Gu, H., He, Q., and Gong, D., 2013. Quality changes and internal browning developments of summer pineapple fruit during storage at different temperatures. Scientia Horticulturae 151, 68-74.

Hossain, M., and Bepary, R.H., 2015. PostHarvest handling of pineapples: a key role to minimize the post-harvest loss. International Journal of Recent Scientific Research, 6(9) pp. 60696075.

http://prsvkm.kau.in. Accessed on $24^{\text {th }}$ April 2018.

http://prsvkm.kau.in/book/variety Accessed on $26^{\text {th }}$ April 2018.

http://www.nistads.res.in/indiasnt2008/t6rural /t6rur14.htm accessed on 10th May 2018.

Jha, S.N., Rai, D. R., and Shrama, R., 2012. Physico-chemical quality parameters and overall quality index of apple during storage. J Food Sci Technol, 49(5): 594-600.

Joy. P. P. and Rashida Rajuva. T.A., 2016. Harvesting and post-harvest handling of pineapple. Kabir, H., Howlader, J., Ghosh, T. K., Goswami, C., and Haque, M. A., 2010. Effects of different maturity phases and post-harvest treatments on the shelf life of pineapple. Int. J. Bio Res. 2(11): 11-16.

Kamol, S.I., Howlader, J., Sutra Dhar, G. C., and Aklimuzzaman, M., 2014. Effect of different stages of maturity and postharvest treatments on quality and 
storability of pineapple. J. Bangladesh Agril. Univ. 12(2): 251-260.

Lobo, M.G., and Siddiq, M., 2017. Overview of pineapple production, postharvest physiology, processing and nutrition. Handbook of Pineapple Technology Production, Postharvest Science, Processing and Nutrition, Edited by María Gloria Lobo and Robert E. Paull. Published by John Wiley \& Sons, Ltd. U.K.

Ranganna, S., 1994. Manual of Analysis of Fruit and Vegetable Products. Tata Mc
Graw-Hill Publishing Company Limited, New Delhi.

Rekha, A., Kumar, A. R., Thondaiman, V., Balamohan, T.N., 2013. Pineapple. Fruit production in India. Edited by WS Dhillon. Narendra publishing house, Delhi-110006 (INDIA).

Shamsudin, R., Daud, W. R. W., Takriff, M. S., and Hassan, O., 2007. Physicochemical Properties of the Josapine Variety of Pineapple Fruit, International Journal of Food Engineering. 3(5): 1-12.

\section{How to cite this article:}

Md. Manzar Hossain, Tokivi Zhimomi, P.S. Nupani and Singh, A.K. 2018. Studies on Change in Physico-Chemical Parameters of Pineapple Fruits of Cultivars Kew and MD-2 during Storage at Ambient Temperature. Int.J.Curr.Microbiol.App.Sci. 7(06): 891-899. doi: https://doi.org/10.20546/ijcmas.2018.706.105 